\title{
Business geo-politics, geo-economics and the fourth Industrial Revolution: An interview with Maxim Shashenkov (Arterial Capital Management)
}

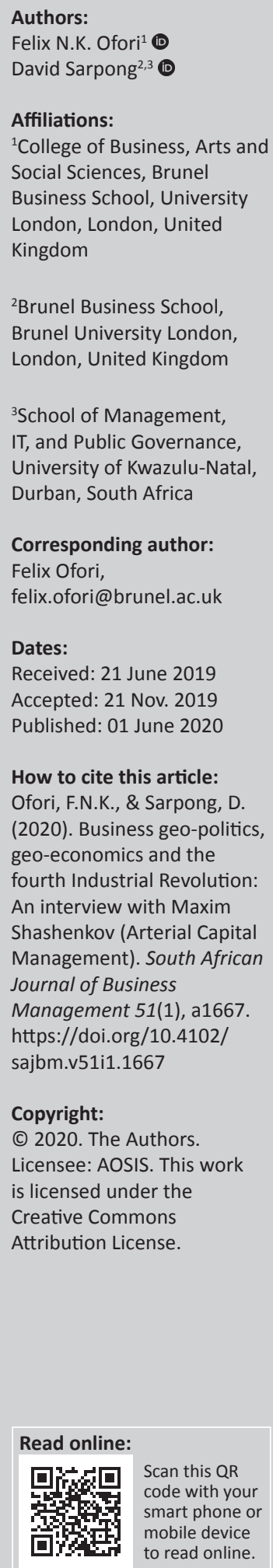

The changing dynamics and unpredictable forces of geo-politics and geo-economics have implications for leadership, politics, businesses and especially those in the financial and equity markets. However, these dynamics remain elusive to most business leaders who fail to adopt creative solutions in turning such challenges into lucrative and sustainable business enterprises. This article premises on an interview with Maxim Shashenkov, managing director of Arterial Capital Management, where he ponders on the complexities of the geo-politics and geo-economic rivalry that defines the current international business arena.

Keywords: geo-politics; geo-economics; leadership; creativity; management.

\section{Introduction}

Maxim Shashenkov has an enviable accomplishment of 25 years of experience in dealing and managing private equity or wealth management in the United Kingdom as well as in Switzerland and Russia. Currently, he is the managing director of Arterial Capital Management - a private equity firm, based in the United Kingdom, which seeks to invest in biotech, MedTech and pharmaceutical companies. Prior to joining Arterial, he worked as an investment banker at Smith New Court and Merrill Lynch, both based in London. Later, he was hired by a Russian oligarch - Mikhail Friedman - as head of equity at Alfa Capital Markets, where he doubled as a member of the Board for London, New York and Russia. After 9 years at Alfa, Maxim moved to Gazprom bank where he established and developed the Pan-European Equity Business. Later, he spent 5 years with the Ural Sib Capital where he managed the London and Moscow operations. As a senior adviser at Private Investment Management (PIM) with responsibilities for handling the markets of London and Geneva, he advised on implementing business strategies as well as successfully developing the Russian or Commonwealth of Independent States (CIS) client base.

Educated at Oxford University (D. Phil, International Relations and Middle Eastern Studies) and Lomonosov Moscow State University (MSU, BA Hons), Maxim began work as a researcher for some leading Russian politicians. With fluency in three languages - Arabic, English and Russian - Maxim has extensive professional networking with businesses and political leaders in Europe, Russia, USA and the Arab world. He has written a book, titled Security Issues of the exSoviet and Central Asian Republics.

In this interview, Dr Maxim Shashenkov explains his thoughts on the absence of creative leadership needed to manage the intricacies of tensions related to geo-politics and geo-economics in the international business environment, as well as training present and future graduates or managers to seize the opportunities inherent in the 2020s, 2030s and beyond.

He ponders that although the 2020s, 2030s and the fourth revolution hold prospects of disrupting the labour markets with the introduction of artificial intelligence (AI), underpinned by geopolitics and geo-economic tensions, creative leadership coupled with critical thinking employees would thrive in those circumstances; this is because a range of opportunities lie unexplored in those areas.

This interview took place just before Maxim delivered a talk as part of the Brunel Business School speakers' series, Brunel University, in February 2019. In its second year, the Brunel Executive Series is a forum where global business leaders and influential industry captains come to share their 
stories, expertise and thoughts on the challenges, issues and decisions made at the highest level of strategic leadership. The series is now a major part of the Brunel Business School's public engagement activities. It brings together academics, students, alumni and local businesses to interact and network in a scholarly and friendly environment. The structure of this article is as follows: it commences with the concept of geopolitics, geo-economics and the fourth revolution. It explores the opportunities and threats that pervade the international business arena. Furthermore, this article explores the strategic policies and management or leadership qualities that businesses require to navigate the geopolitical terrain in order to be successful. In addition, it discusses the corrupt practices as well as the arrest of Michael Calvey in Russia, and its impact on the equity investment and the implications of geopolitics on African businesses. Finally, he discussed issues related to Brexit, cyberattacks and future strategies for sustainable operations.

\section{The interview with Maxim Shashenkov}

\section{Question: What is business geo-politics, geo- economics and the fourth revolution all about?}

\section{Maxim}

There are many developments taking place in the international spheres of politics which have implications for businesses, especially the equity market. For example, there is the US-Russia geo-political struggle, which is creating tension, not only in both states but also persistently undermines global business activities, resulting in severe socio-economic hardships for the peoples beyond both states - Ukraine. In addition, the China-US trade disputes regarding intellectual property are an example of geo-economic tension that is destabilising the stock and equity market activities in the US and Western capitals with adverse consequences in Asia and elsewhere. Furthermore, the emergence of AI coupled with robotic engineering has introduced efficiency in the manufacturing and processing of goods and services, thereby reducing wastage to help spur growth in commercial operations. However, this technological development, which characterises the fourth revolution, has the potential to harm the prospects of the socio-economic fabrics of society by giving rise to unemployment. Thus, one is disinclined to predict the future because of the tension-prone climate in which geopolitics and geo-economic forces are shaping the frontiers of the international business, including the equity market.

\section{Question: What are the opportunities for growth in the equity market given the political uncertainties of the United Kingdom's Brexit?}

\section{Maxim}

The equity market will experience good fortunes and continue to grow regardless of the political uncertainties associated with Brexit now and afterwards. I say this because there are always new markets into which one can enter. For example, there are opportunities in the Chinese, Indian and even the Russian markets where fund managers can strategise to leverage benefits. Moreover, considering the fact that China and India put together constitute a huge source of opportunity for the equity industry; all that is required is the ability to think creatively and critically in such situations. In addition, there are equally good opportunities in France, Germany, Switzerland and in other European states; opportunities exist for the equity market to grow as well as to promote the interests of its customers and the business community as a whole. For example, in the past weeks, I attended a conference of fund managers in Switzerland, where the fund managers deliberated with wealthy individuals regarding a prospect to set up an exclusive private fund dedicated to health programmes, with a single objective to promote human longevity. The amount of money proposed for this venture amounts to billions of pounds. Therefore, within Europe, there are good prospects for expansion and growth regardless of the associated risk with Brexit. However, this does not negate the possible socio-economic uncertainties that a no-deal Brexit would bring in its wake for people and businesses alike.

\section{Question: Do you envisage any threat to the equity market in particular?}

\section{Maxim}

Honestly, threats are pervasive in the geo-politics and geoeconomic environments all the time. For example, these threats manifest themselves in politico-economic sanctions, namely, expelling of one state's diplomats, impositions of trade-tariffs and trade embargoes including freezing of assets - these measures stifle the efficient management of international trade and the equity business. In addition, the threat may culminate in introducing policies, laws or regulations, which may restrict the operations of the equity market, with the consequence of economic stagnation giving rise to job losses, closures or collapses of finance-related businesses in a given country. Theses situation are unfavourable to any business environment; however, they will not affect the 'non-doms' who are often investors in the equity market or business.

\section{Question: You mentioned the 'non-doms' as the biggest investors in the equity market, who are the 'non-doms'?}

\section{Maxim}

Oh yes, the 'non-doms' are people or foreigners not domiciled or resident in the UK but are the biggest investors in the equity market. These people are from foreign countries outside the UK and European Union (EU) and have invested heavily in the equity market. These people come from the Arab countries, China and Gulf states. These 'non-doms' are critical to the survival of the equity markets because without them, UK's economy will suffer dramatically.

\section{Question: As a leader of a private equity or fund management, what strategies or policies are you adopting to respond to the geo-politics and the geo-economic uncertainties of the post-Brexit era?}

\section{Maxim}

Well, we have considered some options but the best strategy we have adopted is that we have set up an entity in Dublin 
(Ireland), which is in full operation. One of the sustaining attributes of a leader in these times of geo-politics and geoeconomics uncertainties is the ability to think creatively to synergise solutions to address unpredictable situations. I believe that the choice of Ireland fits our strategic vision for post-Brexit in two ways: Firstly, the laws of Ireland are similar or EU compliant, therefore, whatever the outcomes of the UK's post-Brexit deal, we would be able to operate in the EU markets with little or no distortion to our activities and that of our clients. Secondly, with a base in Ireland, we have a backup or platform on which to operate in the UK as well as to extend our operations to other parts of the world. This policy has been achieved through critical and visionary thinking - an attribute very much in demand at the turn of the 21st century for success in business and geo-economic endeavours.

\section{Question: What leadership or management style(s) does one require to sustain growth in the equity industry amidst these geo-politics and geo-economic dynamics, internationally?}

\section{Maxim}

Businesses require leaders or management teams who are creative and foresightful. They need people with the prowess to spot long-term opportunities, well-informed in geopolitics, geo-economics and with a broad knowledge of subjects in international relations, international law, security studies, economics, finance and accounting. Above all, leaders are eager to learn new disciplines beyond their acquired degrees. This is because a span of knowledge in the disciplines mentioned above offers the leadership of any institution or organisation a broader understanding, insight and an array of perspectives within which to plan and deploy resources to address a situation. The driving forces of globalisation, internationalisation and revolution of business operations, at the turn of the 21st century, demand that a business leader would be better suited to achieve the objectives of their respective engagements. They can do so, if they have expansive knowledge of the global world order rather than the narrowed knowledge of accounting, finance or economics. The same level and standard of expansive knowledge is required of leaders engaged with equity or fund management.

\section{Question: From your background, as you have been involved in developing several equity markets from the scratch, so, what management style(s) is(are) required in order to be successful in the Russian equity market?}

\section{Maxim}

The Russian society is collective by nature, and it is dominated by communist ideologies and values which make them inward looking. For any foreign enterprise to be successful in Russia, the leadership or management would need to be well-versed in the Russian ways of doing things and that requires patience. For example, the bureaucratic system of running government institutions in Russia has influenced those working as public officials in government departments too. It will take on an average 6-24 weeks for a foreign investor to acquire a licence to start a business in the country
(Russia). There is therefore the need to learn to be patient in dealing with the government officials because they prefer to scrutinise forms and related applications by following bureaucratic standards. In addition, the Russian economy, as you may know, is built around oligarchs and powerful political figures who are involved in the technology and military-hardware industries. In that sense, the Russian market is small, evolving and unpredictable. One needs to be proactive and creative with constant strategic policy initiatives to negotiate in the Russian market for success. This explains why a leader needs to have a broader knowledge of the global geo-politics and geo-economic world in order to deploy a sensible strategy. Although changes are being made to improve the business environment to attract foreign investors, however, the pace is still slow but that is the Russian way of doing things.

\section{Question: How do you reconcile the perpetual political and economic tensions between the Western Powers and Russia, so as to establish an efficient equity market benefitting both factions? \\ Maxim}

As pointed out earlier, the international arena is fluid and unpredictable, and the continuous tension between the Western Powers and Russia makes the situation more complex. In the long term, this situation benefits neither Russia nor the Western powers politically or economically. This is because the tension leads to the imposition of unfavourable regulations, which adversely affect the economic prospects of the ordinary citizens rather than the politicians in those respective countries. I suggest that there has be to an attempt on both sides to find amicable ways of dealing with their political differences. The strategy should involve negotiation with an object to separate business issues from political tensions, in order that the citizens in both factions may reap the needed economic prosperity they deserve.

\section{Question: Russia is perceived to be a corrupt country: How does corruption affect the equity market in Russia?}

\section{Maxim}

Well, everything is relative. What can we say Russia is corrupt in relative to? Relative to the Western states, yes. But when you compare Russia with other Brazil, Russia, India and China (BRIC) states, Russia may be regarded as less corrupt because the levels of corruption in those BRIC states are extremely higher than what pertains in Russia. However, Russia is gradually cleaning its mess in that regard by introducing legislative instruments to stem out corruption in the county, especially in the equity market. The measures to rid corruption take time to yield the intended results. In addition, corruption undermines every shade of activity, be it in business or politics. Furthermore, in the equity market, corruption thwarts the dynamics, independence and efficiency required for the free flow of information and activities for the market to achieve optimal results. Therefore, yes corruption is harmful to the growth of the equity market. 
Question: How does the arrest of Michael Calvey in Moscow play into the geo-politics and geo-economics in the equity market?

\section{Maxim}

Well, I would say very shocking. Everyone in the financial market, equity business as well as some politicians in Russia, the UK and USA were really shocked to hear about Michael Calvey's arrest in Moscow on fraud-related charges. Michael Calvey is renowned for his professionalism and integrity and has over 20 years' experience of operating in the equity market in Moscow. Not only is his arrest a major concern for the international business community, family and friends, but it is also a classic demonstration of geo-politics and geoeconomic forces that are poisoning the economic fortunes of the citizens in those countries affected by his arrest. Furthermore, the Russian' government's arrest of Michael Calvey shares semblances to the arrests of Sabrina Meng and Cathy Meng in Vancouver, Canada, as well as two Canadians - Michael Kovring and Michael Sparov - who are being detained in China for banking-related fraud charges. Although the governments of Canada had assigned banking and financial-related charges, China and Russia for arresting those individuals. There is a growing condemnation among business and political leaders around the world, suggesting that the arrests were purely motivated by geo-political and geo-economic motives. Thus, instead of creating business opportunities for the well-being of the international community, geo-political and geo-economic tensions are being exploited to set an adversarial precedent, which is inimical to business prospects.

\section{Question: What calibre of workforce or employees would you recruit into the equity market in respect of the fourth revolution and why?}

\section{Maxim}

The changing terrain of businesses, especially in the area of equity business, requires individuals with a combination of skills that are not limited to one given discipline or subject area. Therefore, the equity industry requires candidates with innovative ideas, critical thinking prowess, well-informed international relations capability, knowledge related to geoeconomics or politics, finance, statistics and many more fields. This is because a candidate with innovative and creative ideas can provide novel solutions to help resolve problems in the fast-changing equity market. A candidate with critical thinking prowess can contribute efficient ideas to resolve emergency problems that are prevalent in the market. A candidate with an in-depth knowledge in international relations and geo-politics is able to devise strategies to manage business operations in politically charged environments; and lastly, a candidate well-versed in finance and statistics is suitable to perform needed calculations and analysis in order to make an informed decision regarding the viability of an investment in a given area or region. Although these are not the entire skills set required, it indicates that a single specialist knowledge, say BSc in accounting alone, would not survive or suffice the broader spectrum of knowledge required for success in the equity industry.

\section{Question: Are cyber-attacks common in the equity industry?}

\section{Maxim}

With the proliferation of third- and fourth-generation technologies including $\mathrm{AI}$, one can hardly ignore the prevalence of cyber-attacks. However, in the equity market and in my own experience over the past years, we have not experienced any major cyber-attacks yet. Perhaps, the reason is that we work in small teams of 5-10 people on dedicated platforms, so we are able to monitor the system quite regularly to curb such a problem. Yet, one cannot be too complacent to ignore the threat because of the complex and sophisticated hacking systems that are around today.

\section{Question: What are the economic consequences of cyber-attacks on the equity industry? \\ Maxim}

The economic consequences would be hard to quantify. This is because predicting the global economic environment in which the equity market exists is not an easy task. One thing is for sure though, that is, both the equity market and other financial traders would suffer severe financial losses with the prospects of businesses collapsing. For example, the equity market thrives on information, and the ability to exchange information with other partners in the industry speedily and uninterruptedly is key to success. Thus, in an event of a cyber-attack, all activities pertaining to the market may be destroyed within a matter of minutes. This, in turn, will affect the traders' and investors' prospects because the absence of trading activities as a result of cyber-attack means little or no prospects of earning commission. Likewise, the investors' chances of making any gains on their investments would be hampered. Therefore, the economic consequences will be damaging for all parties involved in the market.

\section{Question: What measures have been adopted by your organisation to deal with cyber-attacks? Maxim}

The simple and straightforward response is none as of now. As mentioned earlier, we operate in small teams of 5-10 people using dedicated platforms; so, the industry is not prone to the hackers as are other governmental organisations like the military and hospitals, etc. However, we cannot continue to operate on 'faith' alone; therefore, some form of backup system is worth considering.

\section{Question: How optimistic are you of the equity market's future in light of the geo-politics, geo-economics and the fourth revolution of the 2020s and the 2030s?}

\section{Maxim}

I am an optimistic person and a believer in human spirit and its capability to triumph in times of adversities. In addition, my human instincts tell me that human beings can work together to achieve the best result for the well-being of society 
and generations yet unborn. These strong instincts come from my Russian background. Russians are by nature very optimistic and believe in a collective drive to achieve a common good. For example, human beings can come together, under the guise of a visionary leader, to initiate policies, propose legislations or regulations to resolve the pervading geo-politics and geo-economic tensions swirling around the international business environment so as to promote human development. Similarly, with creative leadership, human strength and goodwill could be harnessed to control some of the threats emanating from $\mathrm{AI}$ in order to reverse the impending dangers of unemployment created in some Western states. Finally, the collapse of the soviet blocs is ample manifestation that human strength or spirit can be organised to achieve unimaginable good for society, businesses and people everywhere. This is possible with a visionary and creative leadership.

\section{Commentary}

There are many issues in this interview which warrant further debate or discussion; however, I will briefly explore two main topics, geopolitics, geo-economics, and how they impact and shape these policies and strategies of developed states in supporting the economic activities of their multinational corporations (MNCs).

This interview suggests that geopolitics has regained prominence at the fore-front of the foreign policy agenda of some developed states (the United States, the United Kingdom, China and Russia) developed at the turn of the 21 st century to vie for a greater share in international trade as well as political benefits across certain regions of the world (Kelly, 2019). Citing recent examples of the inter-state conflicts among China-United States and Russia-United States, Maxim pointed out that geo-political dynamics is shaping the international economic arena. Some powerful states perceive it as a tool to leverage or intimidate weaker economies in order to secure economic gains. This, Harari (2018) explained as driven by the:

$[N]$ ationalistic forces of some states to gain global political dominance, economic supremacy or the fear of rising competition from the eastern economics, to adopt strategies to seize territories beyond their spheres of influence. (p. 113)

To manage the tension and unpredictability characterising the international business terrain of the 21st century, a commentator suggests that the United States and its allied Western states should extend a conciliatory and collaborative hand to the emerging economies, including Russia and China, to find a common solution, which promotes their mutual well-being and the common good of the world (Harari, 2018). He also explained that in a stable and predictable environment, humanity and society flourish and that is true for the equity market too (Harari, 2018).

Conventional geopolitical tensions are active in the policies of the world powers regarding competition for energy resources. In this regard, Muratbekova (2014) argued that:
$[R]$ ather than nationalistic interest, geopolitics should be integrated into university curriculums, and should be emphasised, particularly, in business schools so that future business leaders can develop and cultivate the knowledge and skills required to understand the operations of global political forces. (p. 19)

That is what will make them rethink their decisions, to devise and implement strategic business policies that promote the global well-being of humanity. By way of analysis, the suggestion is that the primary wisdom of geopolitics, where states vie for control over territories as a tactic to promote national economic interests, should give way to a collaborative strategic planning at the global front, led by developed states to advance the fortunes of humankind, irrespective of status, power or wealth (Tagliapietra, 2012). That way, inter-state conflicts and tensions could be minimised to foster a congenial atmosphere that is supportive of businesses including equity-related activities.

Regarding geo-economics, scholars have cited some examples, arguing that geo-economics that deploys economic sanctions as a weapon is 'war by other means' (Wigell \& Vihme, 2016). Thus, geo-economics could be considered as a geostrategic use of economic power to manipulate or influence a target for an exclusive interest. In that sense, the view that the Iraq war is an example of a traditional natural imperial aggression geared to monopolise and control oil resources, with a strategic objective to neutralise interests from Russia's Lukoil and France's TotalFinalElf, is a plausible proposition (Roberts \& Secor, 2003). Roberts and Secor (2003) argued that 'geo-economics is fomenting complex and fractious tensions for international businesses and politics now and the future' (p. 890). The complexity of geo-economics had become pronounced when reflected against the background of China's policy of 'Road and Belt', which is wooing states in the south pacific and Africa to its course. China's strategy of providing infrastructural development and financial facilities to those states without interfering in their internal politics has yielded positive results for China (Yeh, 2016). Furthermore, the consequence is that Western states are introducing uncalibrated counter geo-economic measures in an effort to minimise the influence of China; however, those measures are producing adverse outcomes with the conflict in Ukraine cited as an example. Moreover, the business agreement negotiated between Italy and China has attracted opposition from the EU on one hand and created tension between the EU and Italy on the other hand (Peel, Kynge, \& Hornby, 2019).

Nevertheless, to stem the geo-political and geo-economic tensions bedevilling international business of the 21st century, Maxim has suggested a need for creative thinking among businesses and political leaders to generate new and novel ideas on a regular basis to promote human well-being. In Maxim's view, global business leaders resident in Europe and the United States need to nest strategic partnership agreements with governments and businesses in developing states, especially Africa. This is because the geo-economic and geo-political forces sweeping the corridors of Western powers, China and Russia have implications for Africa too. 
Maxim explained that for African states to benefit from the fourth revolution and its accompanied socio-economic prosperities, a strong and creative leadership is required at the continent level to produce sustainable and creative solutions to generate jobs and provide social infrastructures for the general populace. In that sense, Naidoo, Hewitt and Bussin (2019) had suggested that:

$[A]$ frican leaders should promote an unfettered politico-business environment, which is conducive for the peoples to generate lasting creative ideas to solve their economic and social problems, because creatives in themselves are not effective panacea to human wellbeing. (p. 3)

In addition, some scholars proposed that organisational leaderships in South Africa as well as in each state of Africa need to be trained in new knowledge, skills and abilities to understand the nuances of the Western powers' geo-political and geo-economic forces so that sustainable alternative strategies that promote the unique circumstances of the African peoples are implemented (Terblanche, Albertyn, \& Peter, 2018). Furthermore, Taylor and Lynham (2013) also claimed that 'there is a need to manage the current technological developments to promote human security without exploitation' (p. 91). This argument resonates with Maxim's fore proposition that governments have the power to protect humanity against the adverse effects of AI.

Thus, at the municipal levels, African leaders would have to pass and enforce legislative or regulative measures that protect jobs and ensure the security of their citizens. Moreover, Taylor and Lynham (2013, p. 92) had suggested that a 'leadership, which understands the dynamic interplay between individual, organisation and society, is required to lead Africa's development and growth'. This means that Africa as a continent can promote the well-being of its peoples, in the face of such geo-political and geo-economic tensions, provided they are able to assemble visionary leaders imbued with the qualities alluded to by Maxim in the interview above.

\section{Concluding thoughts}

In this interview, Maxim has shown that geo-politics and geo-economic forces are actively at play in shaping the spheres of international business and influencing the strategic objectives of MNCs, which are supported by their national governments. He contended that the equity market, which constitutes a strategic part of the global international business, would survive and remain significant for the 2020s and 2030s. However, businesses that are able to recruit leaders and employees who are wellinformed in geo-politics, geo-economics, international relations, international law, among others, and who are keen to think creatively to produce new ideas, may be relevant to the needs of the equity markets at the turn of the 21st century and beyond. Africa needs creative leadership to chart its peoples through socio-economic, infrastructural and sound political regimes that bring hope and freedom.
Finally, Maxim stated that human strength is capable of resolving complex challenges confronting society, provided it is organised in a concerted fashion.

\section{Acknowledgements}

The authors are grateful to the organisers of the Brunel Executive Speaker Series for arranging the interview with Maxim Shashenkov.

\section{Competing interests}

The authors have declared that no competing interests exist.

\section{Authors' contribution}

All authors contributed equally to this work.

\section{Ethical consideration}

The authors confirm that ethical clearance was not needed or required for this study.

\section{Funding information}

This research received no specific grant from any funding agency in the public, commercial or not-for-profit sectors.

\section{Data availability statement}

Data sharing is not applicable to this article as no new data were created or analysed in this study.

\section{Disclaimer}

The views and opinions expressed in this article are those of the authors and do not necessarily reflect the official policy or position of any affiliated agency of the authors.

\section{References}

Harari, N.Y. (2018). 21 lessons for the 21st century. London: Jonathan Cape Publication. Kelly, J. (2019, March 07). Kaliningrad, the Russian exclave on the Baltic, its biggest source of amber in the world. Demand from China has led to soaring prices, and also a surge in highly dangerous mining of the gem from the seabed. Financial Times, p. 9.

Muratbekova, A. (2014). From Asia to Eurasia: China and India interests in Central Asia. International Relations and International Law Journal, 77(1), 18-27.

Naidoo, S., Hewitt, M., \& Bussin, M. (2019). A leadership model validation: Dimensions influential to innovation. South African Journal of Business Management, 50(1), 1-11. https://doi.org/10.4102/sajbm.v50i1.1294

Peel, M., Kynge, J., \& Honrby, L. (2019, March 07). EU sets target of 2020 for China investment deal. Financial Times, p. 4.

Roberts, S., Secor, A., \& Sparke, M. (2003). Neoliberal geopolitics. Antipode, 35(5), 886-897.

Tagliapietra, S. (2012). The geoeconomics of sovereign wealth funds and renewable energy (pp. 2-5). Deventer: Claeys \& Casteels.

Taylor, R.G., \& Lynham, S.A. (2013). Systemic leadership for socio-political stewardship. South African Journal of Business Management, 44(1), 87-99. https://doi. org/10.4102/sajbm.v44i1.150

Terblanche, H.D., Albertyn, M.R., \& Coller, V.S. (2018). Developing leaders by supporting their transitions into senior positions. South African Journal of Business Management, 49(1), a12. https://doi.org/10.4102/sajbm.v49i1.12

Wigell, A., \& Vihme, A. (2016). Geopolitics v geoeconomics: The case of Russia's geostrategy and its effects on the EU. International Affairs, 92(3), 605-627. https://doi.org/10.1111/1468-2346.12600

Yeh, T.E. (2016). Introduction: The geoeconomics and geopolitics of Chinese development and investments in Asia. Eurasian Geography and Economics, 57(3), 275-285. https://doi.org/10.1080/15387216.2016.1237881 